the deposit the fragments are often welded together to form a rock as tough as a lava flow. Ignimbrites are widely distributed, and it is clear from this book that they are not lacking in the Soviet Union.

Tufflavas and Ignimbrites is a collection of thirty papers by Soviet geologists, presentod at a symposium on the subject in Moscow in 1961. The first part, devoted to general problems of tufflavas and ignimbrites including their genesis, begins with a review, specially revised and brought up to date by the Soviet volcanologist, V. I. Vlodavetz. Tufflavas are described as resembling ignimbrites in that they contain rock-fragments, but they differ from them in having a homogeneous lava base and a somewhat different origin. The papers in the socond part of the book describe many different occurrences, ranging in age from Cambrian to Pleistocene and in geographic position across the continent of Asia (a map at the front of the book locates the occurrences). The third part discusses aspects of the economic geology of ignimbrites. such as their use as building stones.

This is a book for the specialist rather than the general reader. It is a useful addition to the literature on the subject, and will give both an insight into the development of ideas in the Soviet Union and an introduction to new occurrences from the Caucasus and Kazakhstan to Kamchatka.

G. P. L. WALKER

\section{GEOLOGY IN THE SOUTH-EAST}

\section{Geology of the Country around Canterbury and Folkestone}

By J. G. O. Smart, G. Bisson and B. C. Worssam, with Chapters on Palaeontology of the Gault by R. Casey, and on Palaeontology of the Chalk by R. V. Melville, and other contributions by P. A. Sabine, M. Mitchell, G. P. Jones and H. A. Hope Macdorald. (Memoirs of the Geological Survey of Great Britain-England and Wales.) Pp. $\mathrm{x}+337+6$ plates. (London: H.M.S.O., 1966.) 70s. net.

ONE tends to think of the Victorian geologist as a person who, filled with awe at the mysteries of nature, carefully recorded the details of rocks before him without showing any intellectual curiosity towards them. This approach is still followed by the Geological Survey, and is manifosted in its publications. The memoir on the country around Canterbury and Folkestone is no exception. As a report it embodios the worst features of reports: dullness, reiteration, and lengthy lists of irrelevant or trivial information. There are several reviews of the literature which only duplicate the information available in the bibliography, while many topics have an introduction, at general account, and then a detailed account. 'These accounts are always in text form although much of the information could be better presented diagrammatically.

Because the momoir has many authors it is inevitably patchy-thus the section on the Coal Measures is better than those on the Old Red Sandstone and the Lower Carboniforous bocause it takes account of modern sedimentological work. Given that this memoir is in the style of previous memoirs the major criticism that can be levelled at it is that it deals insufficiently with sedimentology and overmuch with the palaeontology in the general toxt. The only serious petrologic investigations reported are those on brick-earths and clay with flints-both in the Recent soction. The work on the Recent section is good and is one redeeming feature of the book.

Considering the major contribution that Percy Allen has made to our understanding of the geology of the Weald, much more prominence than one short paragraph should have been given to his work. Casey's work is better represented (possibly bocause Casoy is one of the occasional authors) and his chapter on the palaeontology of the
Gault contrasts in liveliness with Melville's chapter on the palaeontology of the chalk, which is little more than a list of fossils and a few words on the problems of zonation.

If the memoir functions largely as a local geology book then at $70 s$. it is too expensive. It is true that the detailed descriptions are very much better than the more general passages in this work, but this is only because the general accounts are so bad. The Survey could easily reduco the memoir to a half or two-thirds its present length by rewriting the general sections and replacing much of the detail by diagrams. Let us hopo the new director of the Survey will see the reformation of the memoirs as one of his first duties.

A. M. Marshall

\section{BIOLOGY OF SKIN CANCER}

\section{Carcinogenesis}

Edited by William Montagna and Richard L. Dobson. (Proceedings of a Symposium on the Biology of Skin held at the University of Oregon Medical School, 1965.) (Advances in Biology of Skin, Vol. 7.) Pp. xiii +358 . (Oxford, London and New York: Pergamon Press, Ltd., 1966.) 110s, net.

THE seventh volume in the series Advances in Biology of Skin, edited by W. Montagna and R. Dobson, contains a series of papers on skin carcinogenesis presented at a symposium in April 1965. The book begins with three chapters on tissue homeostasis. Although cancer constitutes a failure in homeostasis, only in recent years, with the work on gene control ${ }^{1}$ and on histones ${ }^{2}$, has much attention been turned to the study of normal control mechanisms. W. S. Bullough and E. B. Laurence's contribution in this field concerns the combined role of tissuespecific chalones (mitotic inhibitors synthesized by cells) and adrenal stress hormones in the control of epidermal cell mitosis ${ }^{3}$. O. H. Iversen, who recently confirmed the existence of epidermo-specific chalones ${ }^{4}$, discusses the kinetics of the reaction of mouse epidermis to chemical carcinogens and other irritants. Whereas othor workers (particularly those anxious to find a quick-screening test for carcinogens) have stressed the dissimilarities between the response of the skin to carcinogenic and non-carcinogenic hyperplasia-producing irritants, Iversen concludes that the dynamics of the responses to single applications of the two are similar. This similarity, however, does not apply to the repoated application of carcinogens. In the latter case, cell loss becomes progressively less after each application, which suggests tho acquisition by cells of an increasing capacity to resist damage from the carcinogen. T. S. Argyris continues the same general theme by discussing the induction of proliferation in normal tissues by substances derived from tumours, and the relationship between such substances and embryonic inducers ${ }^{5,6}$. The best example of such a substance is the nerve growth factor (NGF) of Cohen and Levi-Montalcini ${ }^{7}$, a protein isolated from the microsomal fraction of a transplantable mouse tumour which stimulates the growth of chick ombryonic ganglia in tissue culture. A further recent development in this field is the isolation of an epidermal growth factor (EGF) from NGF (ref. 8). It would be interesting to see the relation, if any, between EGF and the chalones referred to previously.

H. Kirkman discusses the role of sex hormones in hair follicle tumorigenesis (chaetepithelioma induction) with particular reference to the scent gland of the Syrian hamster; and A. W. Horton, P. A. van Dreal and E. L. Bingham put forward the theory that cortain long chain hydrocarbons accelerate (promote), and cortain polycycloparaffinic compounds delay, carcinogenesis by an effect on the immune response. The evidence for this interesting theory is indirect and corroboration is certainly 